\title{
The use of PCR-RFLP as an identification tool for two closely related species of bats of genus Platyrrhinus
}

\author{
Juliana Machado Ferreira ${ }^{1}$, Felipe de Melo Martins ${ }^{1}$, Albert Ditchfield ${ }^{2}$ and João Stenghel Morgante ${ }^{1}$ \\ ${ }^{1}$ Universidade de São Paulo, Instituto de Biociências, Departamento de Biologia, Laboratório de Biologia \\ Evolutiva e Conservação de Vertebrados, São Paulo, SP, Brazil. \\ ${ }^{2}$ Universidade Federal do Espírito Santo, Departamento de Biologia, Vitória, ES, Brazil.
}

\begin{abstract}
The bat species Platyrrhinus lineatus and $P$. recifinus (Phyllostomidae: Stenodermatinae) are ecologically important because of their capacity for seed dispersal. $P$. recifinus is endemic to the Atlantic rain forest and is considered vulnerable by the IUCN. The lack of distinct morphological features makes identification of the two species a difficult task. This study was aimed at testing the hypothesis that these are actually two distinct species by using PCR-RFLP of the mitochondrial cytocrome $b$ gene. The results showed no shared haplotypes, demonstrating that these are, in fact, two distinct species. No polymorphism was obtained for $P$. recifinus, which could be a sign of low genetic diversity in this threatened species.
\end{abstract}

Key words: Platyrrhinus, PCR-RFLP, identification, Phyllostomidae.

Received: November 19, 2003; Accepted: August 5, 2004.

The species Platyrrhinus lineatus (Geoffroy, 1810) and $P$. recifinus (Thomas, 1901) belong to the subfamily Stenodermatinae, of the exclusive Neotropical family Phyllostomidae. The most distinctive morphological feature of this genus is the white or gray dorsal stripe that extends from head to uropatagium (Eisenberg, 1989). Because of their frugivorous diet, the bats of the subfamily Stenodermatinae are considered as some of the most important seed dispersors, essential for the regeneration of the forests and the colonization of new areas by plants (Altringham, 1996).

The distribution of $P$. lineatus, occurring southeast of the Andes from the Colombian Amazon to Northern Argentina and Eastern Brazil, is wider than the distribution of P. recifinus, which occurs along the Atlantic coast from Eastern Guyana to Eastern Brazil (Eisenberg, 1989). The Atlantic forest has been heavily logged, and less than $7 \%$ of its original area remains forested (Dean, 1995). Therefore, $P$. recifinus is considered vulnerable by the UICN (world situation) and threatened by the IBAMA (situation in Brazil) (Pedro and Aguiar, 1998).

A major problem is that the differentiation between these two species is not simple. Morphological differences

Send correspondence to Juliana Machado Ferreira. Universidade de São Paulo, Instituto de Biociências, Departamento de Biologia, Laboratório de Biologia Evolutiva e Conservação de Vertebrados, , Rua do Matão 277, 05508-900 Cidade Universitária, São Paulo, SP, Brazil. E-mail: jmf0308@yahoo.com.br. are small, there is overlap, and the distinctions between them are based on somewhat subjective criteria. Four out of seven cranial measurements used as distinctive characters overlap (Willig and Hollander, 1987). In the first description of these two species, Thomas (1901) stated that $P$. recifinus had minute and separated upper incisors, just as $P$. helleri. Sanborn (1955), reviewing Thomas' work, suggested that the best distinctive feature was the size of $P$. recifinus, intermediate between $P$. helleri and $P$. lineatus. Taddei (1973) pointed out that there were no distinct external features and stated that the distinction between the two species could only be carried out through a combination of multiple characters. Vizotto and Taddei (1973) stated later that identification is possible using forearm length (41-42mm in $P$. recifinus X $43-50 \mathrm{~mm}$ in $P$. lineatus). Carter and Dolan (1978) argued that the best taxonomic feature for identifying these species was their lower incisors lobation. More recently, Vicente (2000) made a taxonomic review of the genus and concluded that $P$. lineatus has a well-developed posterior projection on the second lower premolar that is absent in P. recifinus. The distinction could further be made using the combination of two characters: the forearm length and the greatest length of skull. However, since large specimens of $P$. recifinus and small specimens of $P$. lineatus are probably often misidentified, the whole issue is fraught with uncertainty.

The major aim of this study was to use molecular tools for testing the hypothesis that these are actually two 
distinct species. Avise (2000) states that, in species with no long-standing barriers to gene flow and life histories conductive for dispersal, no large genetic gaps are expected, and the geographic distribution of lineages will not be heavily localized. Bats normally have high capacity for dispersal and phylogeographic patterns similar to birds and very different from other small mammals (Ditchfield, 2000). Therefore, it is expected that, if $P$. lineatus and $P$. recifinus diverged for a sufficiently long time in evolutionary terms, coalescence among haplotype lineages would lead to reciprocal monophyly. If such were the case, the clades found within $P$. lineatus would be distinct from those of $P$. recifinus. Alternatively, if these two species are actually morphs of a single species, than the haplotype diversity of $P$. lineatus and $P$. recifinus would be the same. Note that, if these two species were sister taxa of very recent origin, the phylogeographic pattern would be similar to that of conspecific populations. However, if $P$. lineatus and $P$. recifinus have distinct haplotype clades, this would have immediate use in taxonomy, because small $P$. lineatus and large $P$. recifinus could be told apart genetically and permit the identification of characters that might work better in species identification for Platyrrhinus.

The samples used in this study belong to the "Laboratório de Biologia Evolutiva e Conservação" (LABEC, IB-USP) and were donated by Dr. Albert Ditchfield, from the Federal University of Espírito Santo (UFES). Dr. Valdir Taddei, from the Universidade Estadual de São Paulo (UNESP), and Dr. Charles O. Handley Jr. (USNMNH) did the specimens identification.

In this work, 38 samples were used: 21 samples of $P$. lineatus comprising 11 different localities, and 17 of $P$. recifinus from 5 localities, all of them from the Atlantic rainforest.

DNA extraction was done using the chloroformphenol protocol by Sambrook et al. (1989). The primers used for PCR amplification were designed using the mtDNA sequence of another Stenodermatinae bat, Artibeus jamaiscensis, available in the genbank (NC_002009). The samples were then digested with restriction endonucleases, as recommended by the manufacturer. Fragment size was calculated using a 100 bp DNA ladder (Invitrogen) and Kodak 1D program.

Fourteen restriction endonucleases were tested and three - MboI, HaeIII and RsaI - were considered informative, i.e., generated different band patterns for both species (Table 1). Two restriction endonucleases generated identical patterns (BamHI and $S s p \mathrm{I})$, and none of the enzymes generated a restriction pattern for just one of the two species.

The band patterns generated by the informative endonucleases were: for $R s a \mathrm{I}$, two bands, of 200 and $1000 \mathrm{bp}$, for $P$. lineatus, and three bands, of 200, 300 and $750 \mathrm{bp}$, for P. recifinus; for MboI (Figure 1), two bands, of 400 and $830 \mathrm{bp}$, for $P$. lineatus, and three bands, of 400,400 and $500 \mathrm{bp}$, for P. recifinus; and for HaeIII (Figure 2), two bands, of 170 and $1100 \mathrm{bp}$, for $P$. lineatus, and two bands, of 345 and $925 \mathrm{bp}$, for $P$. recifinus. Note that the band patterns generated by the informative enzymes are totally different for each species.

Though the sample size was not particularly large, it was possible to detect some intraspecific variability for a $P$. lineatus individual: the enzyme $\mathrm{MboI}$ generated a band pattern of 200, 400 and $600 \mathrm{bp}$. However, we could not detect a phylogeographic pattern, since two species and a large number of localities were sampled, and in all digestions just one pattern considered as a polymorphism was obtained. Such a fact could probably be explained by the molecular marker used (Meyer, 1994) and by the great capacity of dispersal that bats have, due to their ability to fly, which produces a homogenizing effect that prevents the existence of geographically circumscribed lineages, due to high levels of gene flow (Ditchfield \& Burns, 1998).

Moreover, we found two individuals that were identified as $P$. lineatus, but in all digestions we obtained only $P$. recifinus haplotypes. Note that these samples were obtained from another researcher, who had field-identified them using a size-based key (Vizotto and Taddei, 1973), and that the specimens have not been deposited in a museum collection, what kept us from trying to re-identify them. This example highlights the problem of field identifi-

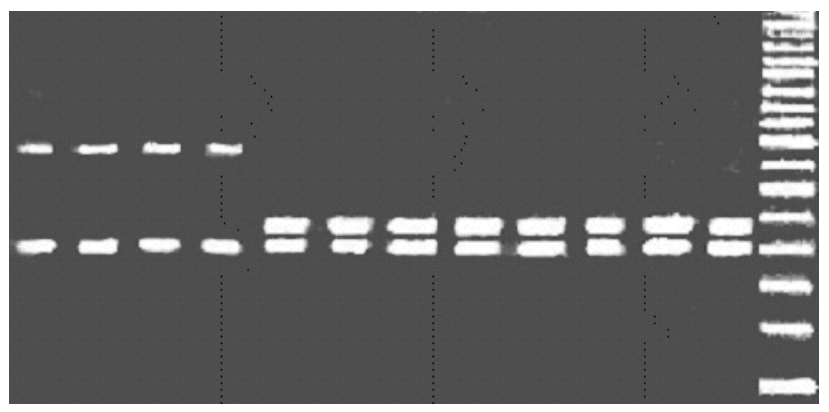

Figure 1 - Band pattern generated by MboI- $P$. lineatus (1-4) and $P$. recifinus (5-12).

Table 1 - Haplotypes: cleavage pattern for each species vs. restriction endonucleases.

\begin{tabular}{lrr}
\hline & \multicolumn{2}{c}{ Species } \\
\cline { 2 - 3 } Restriction endonuclease & P. lineatus & P. recifinus \\
\hline \multirow{2}{*}{ RsaI } & $200 \mathrm{bp}$ & $200 \mathrm{bp}$ \\
& $1000 \mathrm{bp}$ & $300 \mathrm{bp}$ \\
& & $750 \mathrm{bp}$ \\
MboI & $400 \mathrm{bp}$ & $400 \mathrm{bp}$ \\
& $830 \mathrm{bp}$ & $400 \mathrm{bp}$ \\
& Or & $500 \mathrm{bp}$ \\
& $200 \mathrm{bp}$ & \\
& $400 \mathrm{bp}$ & \\
& $600 \mathrm{bp}$ & $345 \mathrm{bp}$ \\
HaeIII & $170 \mathrm{bp}$ & $925 \mathrm{bp}$ \\
\end{tabular}




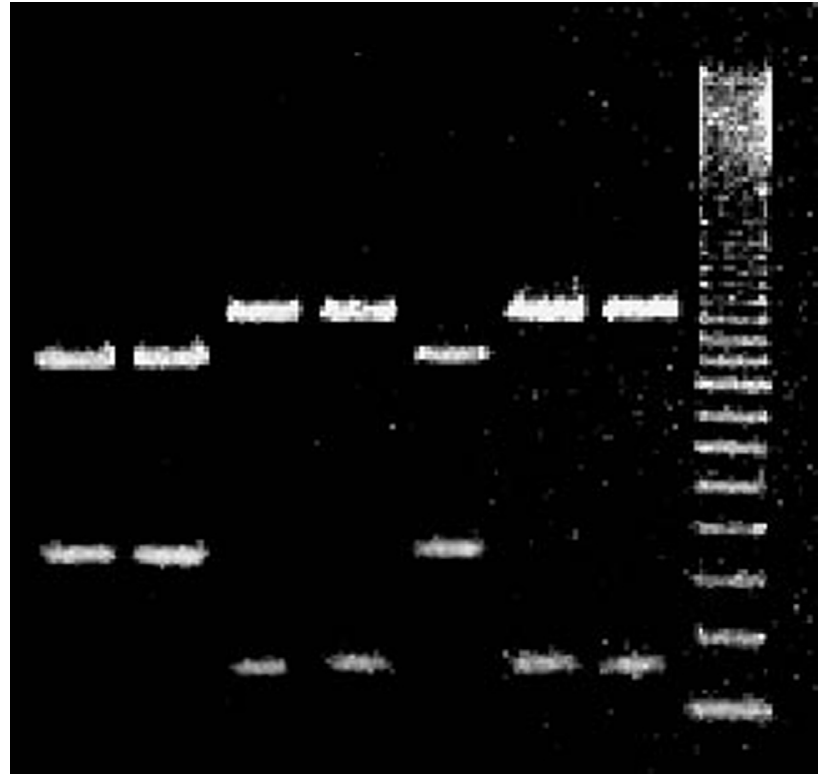

Figure 2 - Band pattern generated by HaeIII-P. lineatus (3,4,6 and 7) and $P$. recifinus (1, 2 and 5).

cation without expert help and demonstrates that part of the confusion regarding the precise species limits for $P$. recifinus and $P$. lineatus might arise from misidentified specimens. Although the specimens were almost certainly misidentified, as these are cryptic species, this could represent a shared haplotype.

As only three of the fourteen enzymes tested generated different cleavage patterns for both species, it is possible to infer that there is a great sequence similarity between $P$. lineatus and $P$. recifinus. These data might reflect the fact that the divergence between these species is low and that the speciation event between $P$. lineatus and $P$. recifinus might have been relatively recent, still, the time since speciation was sufficient for reciprocal monophyly to be attained by these taxa. Moreover, $P$. recifinus had a greater number of restriction sites than $P$. lineatus, three and two, respectively, what may represent either the loss of restriction sites in $P$. lineatus or the gain of new restriction sites in $P$. recifinus.

Therefore, our main conclusion is that $P$. lineatus and $P$. recifinus are indeed two different species, or groups, once a relatively high number of enzymes were tested and no shared haplotypes were found. Since the molecular data supports the morphological hypothesis that these two species are distinct, and $P$. recifinus is endemic of the Atlantic Forest of Brazil, a highly threatened habitat, our results are of interest to conservation authorities - the Atlantic forest must be a priority area for conservation in the future conservation and management plans, and more studies about the phylogeography of $P$. recifinus should be encouraged.

\section{Acknowledgments}

We would like to thank Prof. Dr. Paulo A. Otto for the extreme patience and helpful advice in the analysis of the results. We are also grateful to FAPESP for the financial support (process n. 00/13213-2).

\section{References}

Altringham JD (1996) Bats: Biology and Behaviour. Oxford University Press Inc, New York, 262 pp.

Avise JC (2000) Phylogeography: The History and Formation of Species. Massachussetts, Harvard University Press, 447 pp.

Carter DC and Dolan PG (1978) Catalogue of type specimens of Neotropical bats in selected European museums. Spec Publ Mus Texas Tech Univ 15:52-54.

Dean W (1995) With Broadax and Firebrand, the Destruction of the Brazilian Atlantic Forest. University of California Press, Berkeley, pp 5-30.

Ditchfield AD (2000) The comparative phylogeography of Neotropical mammals: Patterns of intraspecific mitochondrial DNA variation among bats contrasted to non-volant small mammals. Mol Ecol 9:1307-1318.

Ditchfield AD and Burns K (1998). DNA Sequences Reveal Phylogeographic Similarities of Neotropical Bats and Birds. J Comp Biol 3:165-170.

Eisenberg JF (1989) Mammals of the neotropics, the northern neotropics. V1. Panama. The University Chicago Press, Columbia, pp 73-232.

Meyer A (1994) Shortcomings of the cytochrome b gene as a molecular marker. Trends Ecol Evol 9:278-280.

Pedro WA and Aguiar LMS (1998) Platyrrhinus recifinus (Thomas, 1901). In: Machado ABM, da Fonseca GAB, Machado RB, Aguiar LMS and Lins LV (eds) Livro Vermelho das Espécies ameaçadas de Extinção da Fauna de Minas Gerais. Fundação Biodiversitas, Belo Horizonte, pp 62-63.

Sambrook J, Fritsch EF and Maniatis T (1989) Molecular Cloning: A Laboratory Manual. Cold Spring Harbor, Cold Spring Harbor Laboratory, NY, pp 6.4-6.11.

Sanborn CC (1955) Remarks on the bats of the genus Vampyrops. Fieldiana Zool 37:403-413.

Taddei VA (1973) Phyllostomidae da região norte-ocidental do Estado de São Paulo. Ph.D. Thesis, Universidade Estadual Paulista de São José do Rio Preto, São Paulo.

Thomas O (1901) On a collection of bats from Para. Ann Mag Nat Hist, ser 7, 8:192, 193.

Vicente EC (2000) Análises morfológica e morfométrica comparativas em espécies do gênero Platyrrhinus Saussure, 1860 (Chiroptera: Phyllostomidae). Dissertação de Mestrado, Universidade Estadual Paulista, Botucatu.

Vizotto LD and Taddei VA (1973) Chave para a identificação de quirópteros brasileiros. Faculdade de Filosofia, Ciências e Letras, São José do Rio Preto.

Willig MR and Hollander RR (1987) Vampyrops lineatus. Mamm Species. The American Society of Mammalogists 275:1-4.

Associate Editor: Sérgio Furtado dos Reis 